\title{
Pelatihan pembuatan pupuk bokasi dari limbah kotoran ayam untuk meningkatkan kualitas air media budidaya lele Dumbo di Kelurahan Mentangor, Kecamatan Tenayan Raya, Kotamadya Pekanbaru Provinsi Riau
}

\author{
Mulyadi*, Iesje Lukistyowati, Niken Ayu Pamukas, \& Adelina \\ Fakultas Perikanan dan Kelautan, Universitas Riau \\ *mulyadibrian26@yahoo.com
}

\begin{abstract}
Abstrak. Kotoran ayam merupakan bahan organik yang banyak terdapat di Kelurahan Mentangor yang telah dimanfaatkan sebagai pupuk pada saat melakukan pemupukan kolam, namun penggunaan pupuk terus-menerus dapat mengurangi kualitas tanah dasar dan air kolam. Salah satu inovasi teknologi untuk meningkatkan kualitas kotoran ayam tersebut adalah melakukan fermentasi dengan menggunakan $\mathrm{EM}_{4}$ untuk menghasilkan pupuk bokashi. Pupuk bokashi dapat meningkatkan kelimpahan fitoplankton dan zooplankton yang bermanfaat sebagai pakan alami ikan sehingga dapat menekan penggunaan pakan buatan, yang pada akhirnya dapat mengurangi biaya operasional budidaya ikan. Kegiatan pengabdian kepada masyarakat dilakukan untuk tujuan melakukan inovasi pengetahuan dan keterampilan terhadap petani ikan tentang teknik pembuatan pupuk bokashi dari kotoran ayam serta teknik pembuatan pakan ikan berupa pelet untuk meningkatkan produksi ikan budidaya. Kegiatan ini dilakukan dengan metode ceramah, diskusi dan praktek, yang melibatkan kelompok pembudidaya ikan, dan mahasiswa kukerta. Hasil kegiatan pengabdian menunjukkan tingginya antusias petani terhadap kegiatan yang dilakukan, sehingga terjadi peningkatan pengetahuan, wawasan dan keterampilan kelompok tani. Dengan demikian kegiatan budidaya ikan dapat dilakukan petani dengan menekan biaya operasional untuk pengelolaan kolam dan penyediaan pakan sehingga menghasilkan produksi ikan yang tinggi serta dapat meningkatkan pendapatan dan kesejahteraan kelompok tani.
\end{abstract}

Kata kunci: Bokashi, kotoran ayam, EM4, Kelurahan Mentangor

\begin{abstract}
Chicken manure is an organic material that is abundant in Mentangor Village which has been used as fertilizer when fertilizing ponds, however the continuous use of fertilizers can reduce the quality of the bottom soil and pond water. One of the technological innovations to improve the quality of chicken manure is fermentation using EM4 to produce bokashi fertilizer. Bokashi fertilizer can increase the abundance of phytoplankton and zooplankton which are useful as natural fish food so that they can reduce the use of artificial feed, which in turn can reduce the operational costs of fish farming. Community service activities are carried out for the purpose of innovating knowledge and skills of fish farmers regarding techniques for making bokashi fertilizer from chicken manure and techniques for making fish feed in the form of pellets to increase cultivated fish production. This activity is carried out by lecturing, discussion and practice methods, which involve fish cultivator groups and Kukerta students. The results of community service activities show the high enthusiasm of farmers towards the activities carried out, resulting in increased knowledge, insight and skills of farmer groups. Thus, fish farming activities can be carried out by farmers by reducing operational costs for pond management and provision of feed so as to produce high fish production and increase the income and welfare of farmer groups.
\end{abstract}

Keywords: Bokashi, chicken manure, EM4, Mentangor

To cite this article: Mulyadi., I. Lukistyowati., N. A. Pamukas., \& Adelina. 2020. Pelatihan pembuatan pupuk bokasi dari limbah kotoran ayam untuk meningkatkan kualitas air media budidaya lele Dumbo di Kelurahan Mentangor, Kecamatan Tenayan Raya, Kotamadya Pekanbaru Provinsi Riau. Unri Conference Series: Community Engagement 2: 184-191. https://doi.org/10.31258/unricsce.2.184-191

(C) 2020 Authors

Peer-review under responsibility of the organizing committee of Seminar Nasional Pemberdayaan Masyarakat 2020 


\section{PENDAHULUAN}

Kelurahan Mentangor merupakan salah satu kelurahan di Kecamatan Tenayan Raya Kota Pekanbaru yang terletak di Jalan Lintas Timur, terdiri dari 5 RW dan 15 RT dengan jumlah penduduk 6.569 jiwa. Jarak antara Kelurahan Mentagor dengan ibu kota Kecamatan Tenayan Raya adalah $10 \mathrm{~km}$ dan dengan pusat Kota Pekanbaru $12 \mathrm{~km}$. Di Kelurahan Mentangor terdapat kegiatan budidaya ikan yang dilakukan oleh kelompok tani atau Pokdakan Mina Sepakat Jaya yang beranggotakan 10 orang. Ikan yang dibudidayakan adalah ikanikan konsumsi seperti ikan lele dumbo (Clarias gariepinus Burcheel), ikan patin (Pangasius sutchi) dan ikan nila (Oreochromis niloticus).

Untuk meningkatkan kesuburan kolam, selama ini petani ikan melakukan pemupukan menggunakan kotoran ayam dengan cara ditebar begitu saja pada tanah dasar kolam. Penggunaan kotoran ayam terus menerus pada pemupukan tanpa disertai pengelolaan kolam yang baik pada akhirnya dapat merusak kualitas tanah dasar dan air kolam, seperti mengurangi kandungan oksigen terlarut, meningkatkan kandungan $\mathrm{CO}_{2}$ bebas, meningkatkan kekeruhan dan bahan organik yang dikhawatirkan dapat membahayakan ikan-ikan budidaya (Pamukas, 2006). Padahal pemupukan tanah dasar kolam sangat penting karena dapat meningkatkan pertumbuhan pakan alami (plankton dan makrozoobenthos) yang dibutuhkan ikan untuk pertumbuhan. Peningkatan jumlah pakan alami di kolam-kolam budidaya juga dapat mengurangi biaya pembelian pakan buatan sehingga dapat mengurangi biaya operasional budidaya ikan.

Untuk menghindari kerusakan tanah dasar dan kualitas air kolam akibat penggunaan kotoran ayam dalam pemupukan, maka solusi yang dapat dilakukan adalah melakukan fermentasi kotoran ayam dengan memanfaatkan mikroba EM $_{4}$ (Efektif Mikroorganisme-4) menjadi pupuk yang dikenal dengan bokashi. Bokashi merupakan hasil fermentasi bahan organik dari limbah pertanian (pupuk kandang, jerami, sampah, sekam) dengan menggunakan $\mathrm{EM}_{4}$ (Gao et al., 2012). Bokashi mengandung mikroorganisme efektif sebagai dekomposer yang dapat mempercepat proses dekomposisi bahan organik dalam tanah, sehingga dapat meningkatkan ketersediaan unsur hara N, P dan K tanah (Wang et al., 2012). Sedangkan $\mathrm{EM}_{4}$ merupakan bakteri pengurai dari bahan organik yang digunakan untuk proses pembuatan bokashi, yang dapat menjaga kesuburan tanah sehingga berpeluang untuk meningkatkan dan menjaga kestabilan produksi tanah (Ruhukail, 2011).

Menurut Warianto (2006), pemanfaatan bokashi secara teratur dan rutin pada pemupukan kolam dapat meningkatkan kesuburan tanah dasar, menggemburkan tanah, meningkatkan sifat fisik, kimia dan biologi tanah menjadi lebih baik. Hasil penelitian Pamukas (2007) dan Pamukas et al. (2010) menunjukkan bahwa, pupuk bokashi campuran kotoran ayam dan burung puyuh dengan $\mathrm{EM}_{4}$ dapat meningkatkan kelimpahan fitoplankton dan zooplankton, seperti; Scenedesmus sp, Pediastrum sp dan Nitzchia sp serta kelimpahan makrozoobenthos, seperti; Chironomidae dan Culicidae, yang merupakan pakan alami bagi ikan. Menurut Radjam (2008) teknologi penggunaan pupuk bokashi menghasilkan perbaikan pada struktur tanah yaitu dapat meningkatkan kandungan bahan organik tanah, nitrat tanah, fosfor tanah, oksigen terlarut, kesadahan, nitrat air dan orthofosfat air, selanjutnya suhu air, $\mathrm{pH}$ tanah dan air berada dalam kisaran yang baik untuk kehidupan ikan.

Teknologi pembuatan bokashi ini membutuhkan biaya yang cukup murah serta mudah proses pembuatannya. Bokashi dapat dibuat hanya dalam beberapa hari dan langsung dapat digunakan hanya dalam waktu singkat sehingga sangat efektif dan efisien penggunaannya. Permasalahannya adalah petani ikan tidak mempunyai pengetahuan dan wawasan cara mengolah kotoran ayam menjadi pupuk bokashi. Melalui kegiatan pengabdian kepada masyarakat yang dilakukan diharapkan mampu menambah wawasan dan pengetahuan petani ikan sehingga mereka mampu membuat pupuk bokashi secara mandiri dan diaplikasikan pada budidaya ikan.

Selain permasalahan di atas, tingginya harga pakan pabrik (pakan komersil) yang dipakai petani untuk ikan budidaya juga mengakibatkan tingginya biaya operasional budidaya ikan. Untuk mengurangi biaya pembelian pakan, petani biasanya melakukan pemberian pakan tambahan berupa sisa-sisa dapur ke ikan, akan tetapi pertumbuhan ikan menjadi lebih lambat, waktu pemeliharaan lebih lama dan produksi panen rendah. Hal ini terjadi karena pakan tambahan mempunyai kualitas yang lebih rendah. Untuk mengatasi hal tersebut maka petani diharapkan mampu membuat pakan sendiri dengan memanfaatkan bahan-bahan lokal yang kualitasnya baik seperti: bekicot/ keong mas, ampas tahu (Adelina dan Boer, 2011), biji karet (Adelina dan Boer, 2015), dedak dan limbah bulu ayam potong (Adelina, Aryani dan Sukendi, 2018), sehingga pakan yang dihasilkan juga berkualitas baik bahkan harganya relatif murah. Permasalahannya adalah petani ikan di kelurahan ini tidak mampu membuat pakan sendiri, karena kurangnya pengetahuan/ wawasan mereka di bidang tersebut. 
Oleh karena itu melalui kegiatan pengabdian kepada masyarakat dilakukan inovasi pengetahuan dan keterampilan pembuatan pakan mandiri yang murah dan berkualitas baik sehingga dapat meningkatkan produksi ikan budidaya dan meningkatkan kesejahteraan petani ikan.

Berdasarkan uraian di atas, maka dilakukan inovasi pengetahuan melalui kegiatan pengabdian kepada masyarakat terhadap petani Kelurahan Mentangor yang bertujuan untuk meningkatkan wawasan dan pengetahuan petani dalam hal pengelolaan kolam terutama melakukan pemupukan kolam dengan memanfaatkan kotoran ayam broiler yang dicampur dengan $\mathrm{EM}_{4}$ hingga menjadi pupuk bokashi, serta melakukan pembuatan pakan mandiri dengan memanfaatkan bahan-bahan lokal yang harganya relatif murah dan berkualitas baik sehingga dapat mempercepat pertumbuhan ikan dan meningkatkan produksi ikan budidaya yang pada akhirnya dapat meningkatkan kesejahteraan petani ikan di Kelurahan Mentangor.

\section{METODE PENERAPAN}

Kegiatan pengabdian kepada masyarakat di Kelurahan Mentangor dilakukan selama 6 (enam) bulan yang dimulai dari survey lokasi hingga terlaksananya kegiatan. Masyarakat yang dijadikan sasaran kegiatan adalah petani ikan di Kelurahan Mentangor yang mempunyai mata pencaharian utama sebagai pegawai, petani sawit dan karet, penjual bunga dan kebutuhan rumah tangga, serta peternak ayam dan itik.

Kegiatan ini dilaksanakan dengan cara sebagai berikut:

a. Penyampaian materi kegiatan

Materi disampaikan dengan metode ceramah oleh dosen yang berkompeten di bidangnya. Sebelum materi disampaikan, terlebih dahulu dibagikan hand out untuk memudahkan petani memahami materi yang akan disampaikan. Kegiatan ini dilakukan di ruangan milik salah satu petani. Metode ceramah ini diikuti dengan penyampaian alat peraga dan peragaan gambar.

Materi yang disampaikan tentang cara pembuatan pupuk bokashi adalah:

1. Manfaat melakukan pemupukan dengan pupuk bokashi pada kolam budidaya ikan.

2. Kandungan unsur hara N, P dan K yang terdapat pada kotoran ayam, serta cara mempersiapkan kotoran ayam tersebut hingga siap untuk digunakan.

3. Teknik pembuatan pupuk bokashi, mulai dari pembuatan inokulan, persiapan kotoran ayam sampai membuat pupuk bokashi dan penyimpanannya.

4. Teknik melakukan pemupukan di kolam.

5. Teknik memilih benih ikan yang berkualitas baik, dan teknik melakukan penebaran ikan.

Materi yang disampaikan tentang cara pembuatan pakan ikan berupa pelet:

1. Teknik memilih bahan-bahan lokal yang dapat dimanfaatkan sebagai pakan ikan.

2. Teknik mempersiapkan bahan-bahan pakan hingga siap digunakan untuk pakan ikan.

3. Teknik menyusun formulasi bahan pakan.

4. Teknik membuat pakan ikan berupa pelet dan proses pengeringan.

5. Teknik menyimpan pakan ikan yang baik.

6. Teknik menentukan jumlah pakan yang tepat untuk diberikan ke ikan budidaya.

b. Diskusi atau tanya jawab

Diskusi atau tanya jawab dilakukan setelah selesai penyampaian materi baik pada waktu ceramah maupun pada waktu demonstrasi dan praktek. Dengan melakukan tanya jawab antara Tim pengabdian kepada masyarakat dengan peserta yang dalam hal ini adalah petani ikan berarti ada feedback dari peserta, sehingga diharapkan tingkat pengetahuan dan pemahaman materi yang diberikan menjadi lebih baik.

c. Demonstrasi atau Praktek

Peningkatan keterampilan petani ikan dilakukan dengan mengajak petani melakukan praktek pembuatan pupuk bokashi dan teknik pembuatan pakan ikan berupa pelet yang dilakukan di halaman rumah salah satu penduduk. Terlaksananya kegiatan pengabdian kepada masyarakat ini diharapkan dapat meningkatkan pengetahuan, keterampilan dan motivasi para petani di Kelurahan Mentangor sehingga petani mampu memproduksi ikan dengan memanfaatkan pakan alami dan melakukan pemberian pakan buatan sendiri dengan biaya yang relatif murah. Keseluruhan kegiatan tersebut dilakukan untuk tujuan meningkatkan pendapatan atau kesejahteraan petani.

d. Alat Ukur Ketercapaian

Untuk mengukur ketercapaian keberhasilan kegiatan pengabdian kepada masyarakat di Kelurahan Mentangor maka disusun beberapa pertanyaan atau kuisioner untuk peserta. Pertanyaan yang disusun berhubungan dengan 
materi yang telah disampaikan dan praktek pembuatan bokashi dan pembuatan pakan ikan. Pertanyaan tersebut diajukan kepada peserta di awal sebelum kegiatan dimulai serta di akhir setelah kegiatan berlangsung. Perubahan atau peningkatan pengetahuan/ wawasan dan keterampilan petani atau perubahan sikap petani kemudian diukur dan dianalisa secara deskriptif maupun kualitatif.

\section{HASIL DAN KETERCAPAIAN}

Kegiatan pengabdian kepada masyarakat di Keluran Mentangor telah dilaksanakan seperti yang disajikan berikut ini:

\section{Penyajian Materi Penyuluhan}

Kegiatan pengabdian kepada masyarakat diawali dengan pembukaan oleh Bapak RW 11 Kelurahan Mentangor (Gambar 1), kemudian perkenalan ketua Tim terhadap anggota Tim kepada peserta/ petani (Gambar 2). Kegiatan ini juga melibatkan mahasiswa yang melaksanakan KKN integrasi di kelurahan tersebut. Selanjutnya dilakukan penyampaian materi tentang: Teknik pembuatan pupuk bokashi dan Pembuatan pakan ikan berupa pelet, kemudian dilanjutkan sesi tanya jawab mengenai materi yang kurang dimengerti dan permasalahan yang dihadapi petani pada budidaya ikan (Gambar 3). Pada kesempatan ini juga dibagikan kuisioner tentang materi yang telah disampaikan untuk mengukur pengetahuan/ wawasan peserta terhadap materi tersebut.

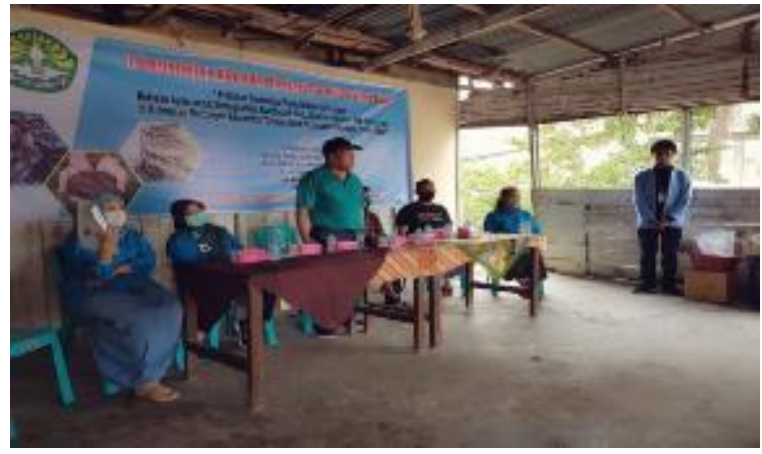

Gambar 1. Pembukaan kegiatan pengabdian kepada masyarakat oleh Bapak RW 11 Kelurahan Mentangor

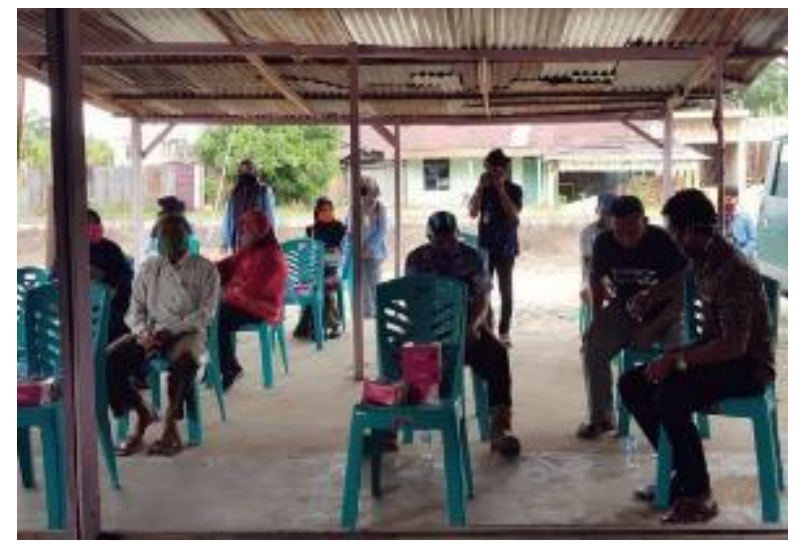

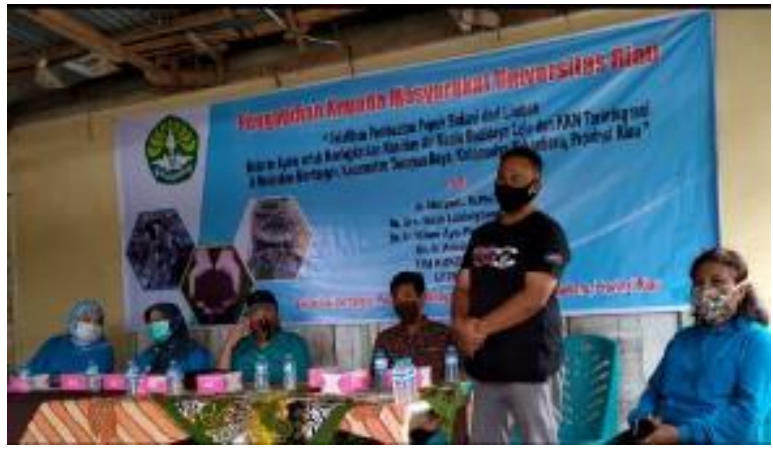

Gambar 2. Kata sambutan dan perkenalan anggota oleh Ketua Tim Pengabdian kepada masyarakat

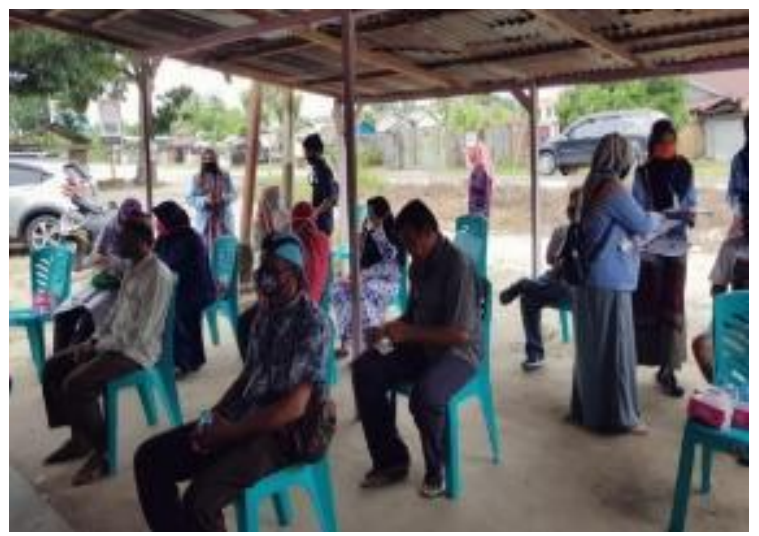

Gambar 3. Peserta kegiatan pengabdian kepada masyarakat

\section{Demonstrasi dan Praktek}

\subsection{Pembuatan Pupuk Bokashi}

Pelatihan pembuatan pupuk bokasi dipandu oleh Dr. Ir. Niken Ayu Pamukas, M.Si. Teknik pembuatan pupuk bokashi dilakukan dengan tahapan sebagai berikut: 
1. Kotoran ayam yang akan digunakan dikeringkan terlebih dahulu di bawah cahaya matahari (Gambar 4), kemudian dibuang sampah-sampah yang tidak diinginkan, selanjutnya kotoran ayam dihaluskan dan disaring agar ukuran butiran pupuk yang dihasilkan dapat homogen.

2. EM4 yang dalam keadaan dorman diaktifkan dan dikembangbiakkan dengan susu kental manis (inokulasi). Inokulan dibuat dengan cara menyiapkan wadah berisi air sebanyak 1 liter, susu kental manis $20 \mathrm{ml}$ dan EM4 $20 \mathrm{ml}$ (Gambar 5). Ketiga bahan diaduk sampai homogen dan dibiarkan beberapa saat atau paling lama 24 jam agar bakteri dapat tumbuh. Inokulan yang bagus ditandai dengan banyaknya koloni-koloni bakteri di permukaan air.

3. Kotoran ayam dicampurkan dengan dedak dan sekam dengan perbandingan $60 \%$ kotoran ayam $(12 \mathrm{~kg})$, $30 \%$ dedak $(6 \mathrm{~kg})$ dan $10 \%$ sekam $(2 \mathrm{~kg})$ untuk $20 \mathrm{~kg}$ pupuk bokasi. Semua bahan dicampur sampai homogen dan tercampur rata. Setelah rata ditambahkan secara perlahan inokulan EM4 sampai lembab dan dibentuk adonan yang dapat dikepal (Gambar 6). Adonan pupuk dimasukkan ke dalam karung goni atau wadah tertutup dan difermentasikan dengan suhu berkisar $40-50^{\circ} \mathrm{C}$ selama $4-7$ hari. Setelah 4 sampai 7 hari pupuk bokasi sudah siap untuk digunakan (Gambar 7).

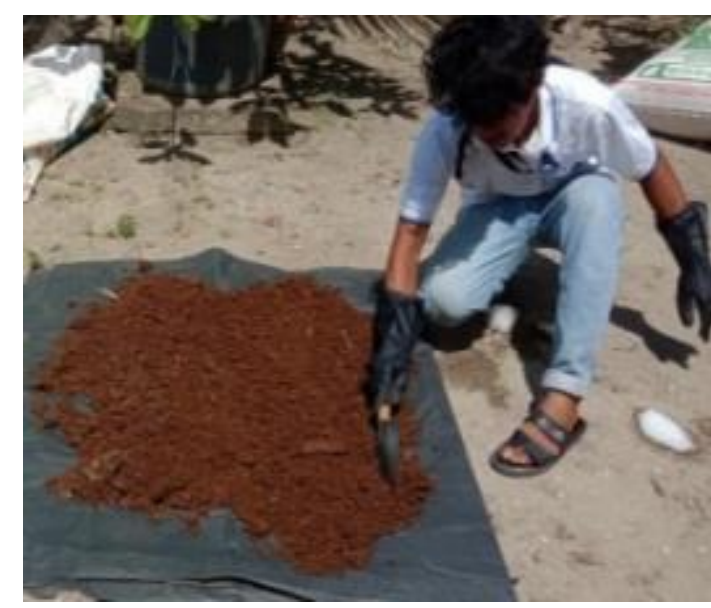

Gambar 4. Pengeringan Kotoran Ayam

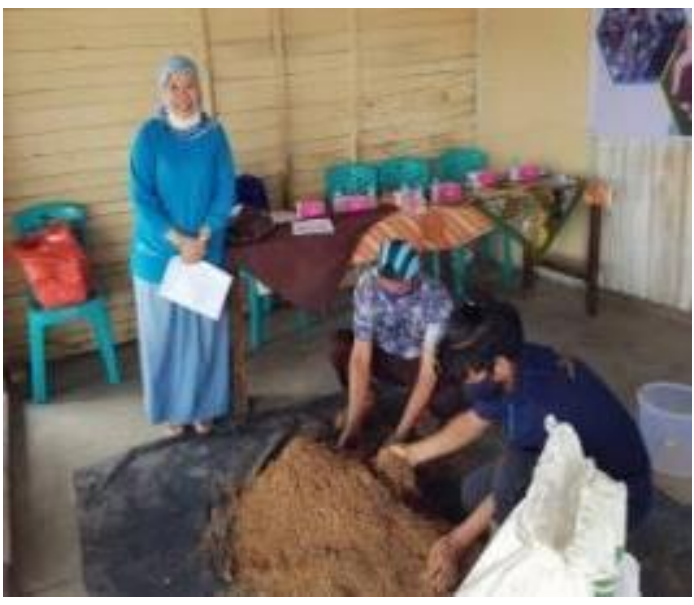

Gambar 6. Pencampuran bahan-bahan

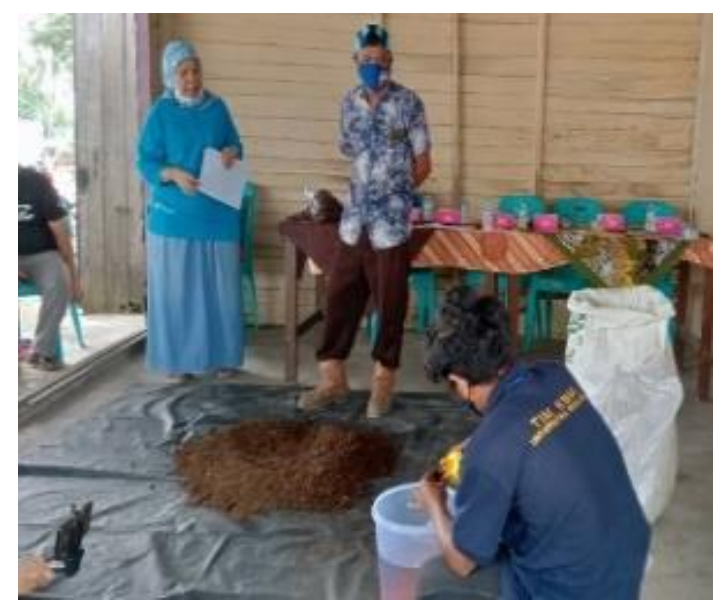

Gambar 5. Pembuatan inokulan EM4

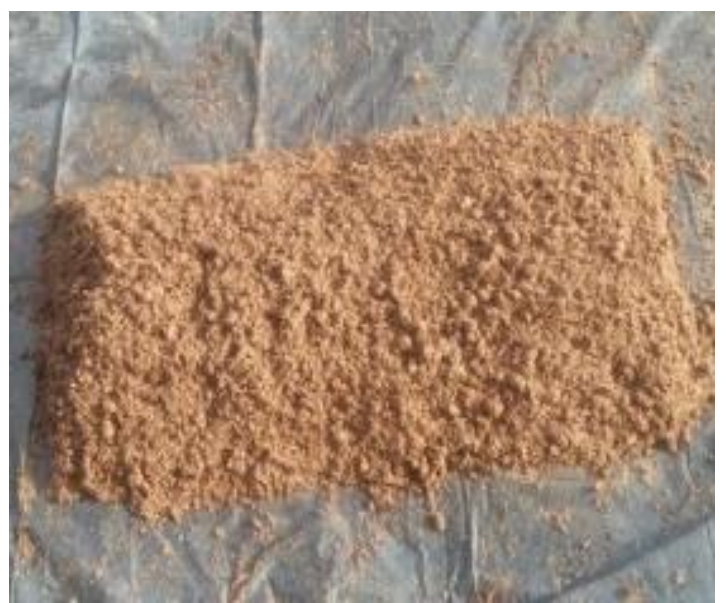

Gambar 7. Pupuk bokasi

Pupuk bokasi adalah pupuk organik (dari bahan jerami/ sekam, pupuk kandang, sampah organik, dan bahan lainnya) hasil fermentasi dengan EM4. Menurut Apnan (1997) pemberian EM-4 aktif bertujuan untuk memperbaiki sifat fisik, biologi tanah dasar dan mempercepat dekomposisi bahan organik serta dapat meningkatkan keragaman dan populasi mikroorganisme pada tanah dasar, sehingga menjadi subur. Selanjutnya Higa (1980) menyatakan bahwa EM-4 dapat menguraikan bahan-bahan organik yang tidak 
diperlukan menjadi bermanfaat dan dapat pula digunakan untuk meningkatkan pertumbuhan phytoplankton dan zooplankton sebagai pakan alami, serta dapat memperbaiki kualitas air sehingga mempercepat pertumbuhan ikan.

\subsection{Pembuatan Pakan Ikan}

Pelatihan pembuatan pakan ikan dipandu oleh Dr. Ir. Adelina, M.Si (Gambar 8). Prosedur pembuatan pakan ikan adalah sebagai berikut:

1. Bahan-bahan pakan berupa tepung ikan, ampas tahu, dedak, tepung terigu, vitamin, mineral dan minyak

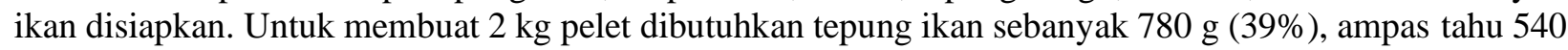
$\mathrm{g}(27 \%)$, dedak $320 \mathrm{~g} \mathrm{(16 \% ),} \mathrm{tepung} \mathrm{terigu} 240 \mathrm{~g}$ (12\%), vitamin, mineral dan minyak ikan masing-masing sebanyak $40 \mathrm{~g}(2 \%)$.

2. Bahan pakan dicampurkan dalam baskom. Bahan yang jumlahnya paling sedikit dimasukkan terlebih dahulu hingga terakhir bahan yang jumlahnya paling banyak. Pencampuran bahan dilakukan sampai homogen, kemudian ditambahkan air hangat sedikit demi sedikit hingga menjadi adonan yang kompak (Gambar 9).

3. Adonan kemudian dicetak menjadi pelet selanjutnya dijemur di bawah cahaya matahari hingga kering dan siap diberikan ke ikan (Gambar 10).

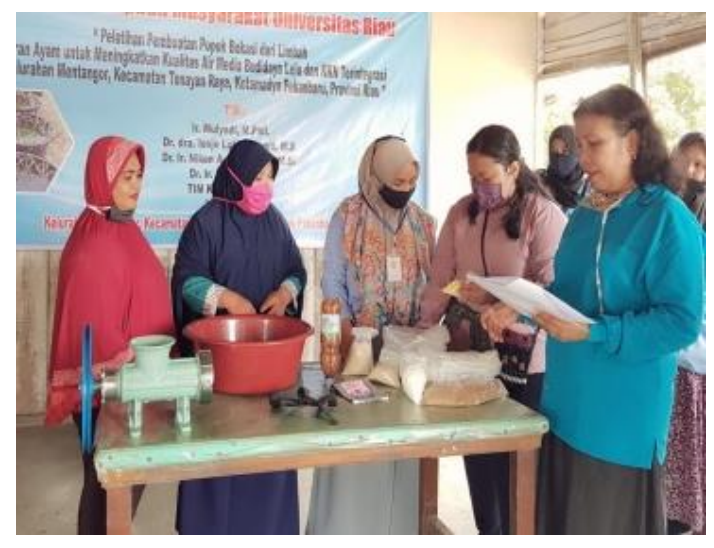

Gambar 8. Penjelasan cara pembuatan pakan ikan

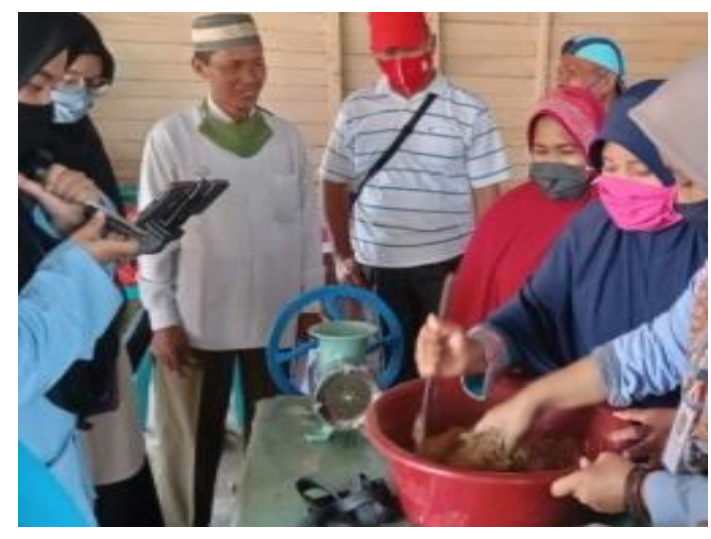

Gambar 9. Pencampuran bahan-bahan pakan

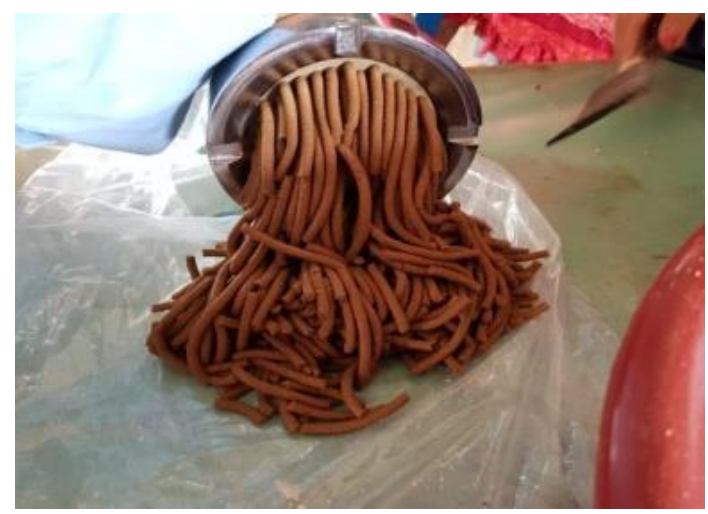

Gambar 10. Pakan ikan berupa pelet

Pelet yang telah dibuat pada kegiatan di atas mempunyai kualitas baik karena dibuat dari bahan-bahan yang berkualitas baik kemudian juga disusun dengan kandungan nutrien (protein, lemak dan karbohidrat) yang memenuhi kebutuhan ikan. Hal ini sesuai dengan yang dikemukakan NRC (1993) yang menjelaskan bahwa pakan harus mengandung nutrien maupun energi yang diperlukan ikan untuk pertumbuhan dan kesehatan ikan. Pelet tersebut juga mempunyai harga relatif murah (Rp. $4.500-5.000 / \mathrm{kg}$ ) dibandingkan pelet komersil yang harganya berkisar Rp. 12.000 - 13.000/ kg. Pelet yang telah dihasilkan kemudian diuji kualitasnya. Kualitas fisik pelet yang telah dibuat petani tergolong baik, karena pelet dijemur dengan baik, kemudian pelet dapat 
disimpan lama dan tidak ditumbuhi jamur. Pelet juga dapat menggumpal dengan baik sehingga tidak mudah pecah di dalam air. Pelet kemudian diberikan ke ikan lele dumbo secara add satiation. Frekuensi pemberian pakan 3 kali sehari yaitu pukul 08: 00, 12:00 dan 16:00 WIB.

\section{Evaluasi Hasil Kegiatan Pengabdian}

Kegiatan pengabdian kepada masyarakat yang telah dilakukan memberi banyak perubahan pada peserta. Perubahan pertama terlihat pada sikap sosial peserta yaitu tingginya motivasi peserta untuk turut serta melakukan praktek pada setiap kegiatan. Hasil evaluasi menunjukkan bahwa terjadi peningkatan pengetahuan/ wawasan dan keterampilan peserta sesudah kegiatan pengabdian kepada masyarakat berlangsung, sekitar 95\% terjadi peningkatan pengetahuan dan keterampilan dalam bidang pembuatan pupuk bokashi, kemudian sekitar 90\% terjadi peningkatan pengetahuan dan keterampilan dalam bidang pembuatan pakan ikan.

Peningkatan pengetahuan dan keterampilan peserta yang terlihat pada kegiatan pengabdian kepada masyarakat adalah meliputi:

1. Peserta memahami manfaat budidaya ikan menggunakan pupuk bokashi.

2. Peserta memahami cara mengaktifkan EM4 dan membuat inokulan.

3. Peserta memahami bahan-bahan yang dapat digunakan untuk membuat pupuk bokashi, serta cara melakukan fermentasi kotoran ayam menjadi pupuk bokashi.

4. Peserta memahami pentingnya menjaga kualitas tanah dasar dan air kolam agar ikan yang dibudidayakan tidak terhambat pertumbuhannya dan dapat dipanen tepat waktu.

5. Peserta memahami bahwa ikan membutuhkan pakan berkualitas untuk dapat hidup dan bertumbuh.

6. Peserta memahami bahwa pakan dapat dibuat dari bahan-bahan lokal yang ada di lingkungan sekitar yang murah harganya.

7. Peserta memahami cara mencampur bahan-bahan pakan dan antusias untuk membuat pelet dengan cara yang baik untuk mendapatkan pelet berkualitas baik.

8. Peserta memahami cara memberi pakan ke ikan dengan jumlah yang cukup.

Kegiatan pengabdian kepada masyarakat di Kelurahan Mentangor diharapkan tidak saja sebatas bertambahnya pengetahuan dan keterampilan peserta terhadap kegiatan yang sudah dilakukan, tetapi juga bertambahnya motivasi peserta untuk melakukan budidaya ikan di kolam dengan menggunakan pupuk bokashi dan pakan buatan sendiri yang kesemuanya bertujuan untuk meningkatkan kesehteraan masyarakat.

\section{KESIMPULAN}

Kegiatan pengabdian kepada masyarakat yang telah dilakukan mengenai teknik pembuatan pupuk bokashi dan pembuatan pakan ikan berupa pellet telah mampu diterima petani dengan baik, bahkan dapat meningkatkan pengetahuan dan keterampilan petani Kelurahan Mentangor. Peningkatan pengetahuan dan keterampilan petani serta motivasi sangat diharapkan untuk dapat menjadi bekal agar kegiatan budidaya ini dapat terus berlanjut dan Kelurahan Mentangor dapat menjadi kelurahan percontohan akan teknik budidaya ikan yang baik kepada masyarakat di sekitarnya. Petani ikan Kelurahan Mentangor telah cukup lama melakukan budidaya ikan lele khususnya pembesaran ikan, namun benih ikan yang mereka gunakan didapat dengan cara dibeli dari petani kelurahan lainnya. Oleh karena itu petani setempat berharap kedepannya dapat diajarkan teknik melakukan pembenihan ikan lele, sehingga mereka dapat menyediakan benih ikan secara mandiri untuk memenuhi kebutuhan budidaya ikan.

\section{UCAPAN TERIMA KASIH}

Terlaksananya kegiatan pengabdian kepada masyarakat di Kelurahan Mentangor tidak terlepas dari kerjasama Tim dengan LPPM UNRI, untuk itu Tim mengucapkan terimakasih karena LPPM yang telah memberi bantuan dana sehingga kegiatan telah terlaksana dengan baik. Ucapan terimakasih juga disampaikan kepada aparat Kelurahan Mentangor dan peserta yang dalam hal ini adalah petani ikan yang telah dapat menerima Tim untuk dapat melaksanakan kegiatan ini. 


\section{DAFTAR PUSTAKA}

Adelina dan I. Boer, 2011. Pemanfaatan Kepala Udang dan Ampas Tahu Sebagai Pengganti Tepung Ikan dalam Pakan Benih Ikan Selais (Ompok hypopthalmus). Prosiding Seminar Antarbangsa ke 4 Ekologi, Habitat Manusia dan Perubahan Persekitaran di Alam Melayu. hal 966-976.

Adelina dan I. Boer, 2015. Pengaruh Penggunaan Biji Karet (Havea brasiliensis) Dalam Pakan Terhadap Pertumbuhan Ikan gurami (Osphronemus gouramy). Laporan Penelitian. Lembaga Penelitian Dan Pengabdian Kepada Masyarakat. Universitas Riau. 60 hlm (tidak diterbitkan).

Adelina, N. Aryani dan Sukendi. 2018. Subtitusi Tepung Ikan Dan Tepung Kedelai Dengan Tepung Bulu Ayam Dalam Pakan Untuk Meningkatkan Kinerja Pertumbuhan Ikan Bawal Bintang (Trachinotus Blochii). Laporan Penelitian. Lembaga Penelitian Dan Pengabdian Kepada Masyarakat. Universitas Riau. 58 hlm (tidak diterbitkan).

Apnan. 1997. Pedoman Penggunaan EM bagi Negara-Negara Asia Pasifik Nature Agriculture Network. Seminar Nasional Pertanian Organik Jakarta, 3 April 1997. 36 hal. (tidak diterbitkan).

Gao, M., J. Li, and X. Zhang, 2012. Responses of Soil Fauna Structure and Leaf Litter Decomposit ion to Effective Microorganism Treatments in Dahinggan Mountains, China. Chinese Geographical Science, 22(6), 647-658.

Higa, T. 1980. Efektif Mikroorganisme. University of the Rykyus Okinawa. Japan. 10 pp.

NRC, National research Council. 1993. Nutrient requirement of fish. National Academy of Science. Washington, D.C. $114 \mathrm{pp}$.

Pamukas, N. A. 2006. Perkembangan Jenis dan Kelimpahan Fitoplankton Dengan Pemberian Dosis Pupuk Kotoran Puyuh Yang Berbeda. Jurnal Perikanan dan Kelautan, XI (2), 109-118.

Pamukas, N. A. 2007. Perkembangan Jenis dan Kelimpahan Makrozoo-benthos Di Tanah Dasar Kolam Dengan Pemberian Pupuk Bokashi Yang Berbeda. Lembaga Penelitian Universitas Riau. 84 hal (tidak diterbitkan).

Pamukas, N. A., Syafriadiman dan A. Irawan. 2010. Perkembangan Kelimpahan Fitoplankton Yang Diberi Pupuk Organik Menggunakan Humic Acid (Ha) Dengan Dosis Yang Berbeda. Kumpulan Hasil Penelitian Teknologi Hasil Perikanan. 82-91.

Ruhukai NL. 2011. Pengaruh Penggunaan EM4 yang Dikulturkan Pada Bokashi dan Pupuk Anorganik Terhadap Produksi Tanaman Kacang Tanah (Arachis hypogaea L.) di Kampung Wanggar Kabupaten Nabire. Jurnal Agroforestri, VI(2), 114-120.

Wang, S., X. Liang, Q. Luo, F. Fan, Y. Chen, and Z. Li. 2012. Fertilization Increases Paddy Soil Organic Carbon Density. Journal of Zhejiang University, 13(4), 274-282.

Wardianto, A. 2006. Pupuk Bokasi Mampu Meningkatkan Produktifitas Jagung BISI-2. http://www.tanindo.com/abdi18/hal2701.htm 